\title{
Evaluating the Rhetoric of Paul's Letter to Philemon: Implications for Master-Slave Relationship in Christian Households
}

\author{
Maxwell Kojo Tsibu (D) 1 \\ ${ }^{1}$ Methodist College of Education, Akyem Asene-Aboabo, Oda- Eastern Region - Ghana.
}

\begin{abstract}
Many kinds of studies have been conducted on Greco-Roman slavery practices and the Christian response to religious and domestic conflicts. However, very little research has been carried out in biblical studies to appraise the rhetoric of Paul's letter to Philemon and its persuasive implications for handling tensions and dilemmas that emerge from master-servant relationships in the Christian domestic contexts. This paper contributes to the scholarship on Philemon by critically interpreting the persuasiveness of the letter. It exposes Paul's intentional use of highly emotive argumentations, familial concepts and visual symbols to influence the beliefs, state of mind, values and contemplated actions of his primary audience regarding a particular distressing exigency. It reveals the strong subversive and transformative tone of the letter. The paper contends that the message of Philemon has effective rhetorical power for managing the challenges faced by Christian parents, maids and fictive children in the Christian household.
\end{abstract}

Correspondence:

Maxwell Kojo Tsibu

Email: maxwelltsibu.k@gmail.com

Publication History

Received 8th February, 2021

Accepted 26th February, 2021,

Published online 3rd March, 2021.

\section{Keywords: Rhetoric, 1st Century Greco-Roman context, master-slave relationship, Christianity, appropriation}

(C) 2021 The Author(s). Published and Maintained by Noyam Publishers.

This is an open access article under the CCBY license (http://creativecommons.org/licenses/by/4.0/).

\section{INTRODUCTION}

Christianity emerged and developed in a cultural context where slaveholders and slaves were part of the everyday landscape. According to the estimates made by Keith Hopkins, ${ }^{1}$ at the end of the 1 st century B.C.E., the Roman realm contained approximately two million slaves out of a total population of six million and many of these slaves became Christians and fellowshipped in the local assemblies with their masters. From the outset of Christian literature, Christian authors, despite their socially marginal position, contended with the social reality of slavery in the ecclesia. In his epistle to Philemon (hereafter, Philem), Paul wrestles with a perplexing domestic issue between a Christian master and (a Christian) slave in the ecclesia. This eponymous letter continues to attract regular attention from scholars regarding how the earliest Christians handled slavery in their fellowships. ${ }^{2}$ Despite numerous fruitful insights earlier studies have produced to expose the message of Philem, there is more to contend with, especially regarding the rhetorical effectiveness of letter in its literary and immediate historical contexts and the reflections that may be deduced for Christian parents, fictive children, maids and servants who find themselves in similar dilemmas in their households. Accordingly, the study critically examines Philem as a rhetorical discourse by focusing on the following salient elements ${ }^{3}$ in the structure of the text: (i) the literary unit, (ii) the rhetorical situation, (iii) the rhetorical species (iv) invention, arrangement, and rhetorical styles and (v) the overall rhetorical effectiveness of Philem. The literary analysis will expose Paul's calculated

\footnotetext{
Keith Hopkins, Conquerors and Slaves, (Cambridge: Cambridge University Press, 1978), 7-9.

Jennifer Glancy, "Slavery and the Rise of Christianity," in The Cambridge World History of Slavery, ed. Keith Bradley \& Paul Cartledge (Cambridge, UK: Cambridge University Press, 2011), 468-4881.

3 George A. Kennedy, New Testament interpretation through rhetorical criticism (Chapel Hill, NC: University of North Carolina Press, 1984). Kennedy's work gives a detail description of the use of rhetorical criticism in the studying of New Testament texts. He argues that the New Testament writers had a message to communicate and sought to persuade an audience to believe it or to believe it more profoundly. His book arguably serves as a primer to rhetorical analysis of early Christian texts for many contemporary readers.
} 
use of language and other symbols intended to influence Philemon to act, to believe, or feel the way the rhetor desired in the rhetorical exigency or situation. The paper contends that the rhetoric of Philem brings out some imperative 'call to action' for Christian masters and servants in contemporary domestic situations.

\section{METHODOLOGY}

This is a literary study; it is purely qualitative. ${ }^{4}$ Hermeneutics ${ }^{5}$ is the interpretive design of the study. In the field of scriptural studies, hermeneutics is seen as the theory, method and practice of how to read, understand, and use biblical texts. ${ }^{6}$ Jeannine K. Brown describes it as "the analysis of what we do when we seek to understand the Bible, including its appropriation to the contemporary world." 7 The chosen literary approach for exegetical reading is rhetorical criticism. ${ }^{8}$ Rhetoric involves carefully choosing words in a communication aimed at persuading the audience into accepting arguments. ${ }^{9}$ Essentially, it can be described as the art of speaking or writing persuasively. This method tries to understand the rhetor's message, how it was constructed and intended to function, and how the audience was likely to have understood and responded to the texts. It allows one to focus on the communication piece between an author and a reader by investigating the strategies the author employs to influence the reader's view or response. As observed by Dany Olinger, "Paul's rhetorical structuring of his letters is deliberate and meaningful as it drives the reader to the heart of his theological argument." ${ }^{10}$ This method is an indispensable literary tool for understanding the function of the text, particularly with regards to its argumentations and the rhetorical force of the argumentations. Employing this method, the researcher will critically evaluate the argumentative strategy adopted by Paul when he was confronted head-on with the disturbing slavery situation of Onesimus. The Greek text ${ }^{11}$ of Philem constitutes the primary data for the study. Other information is drawn from secondary sources such as critical and exegetical commentaries, monographs, and dissertations as well as articles on Philemon scholarship.

\section{i. PHILEM AS A DISCRETE LITERARY UNIT}

Philem is first and foremost a typical Hellenistic letter fashioned to match communicative goals on a particular occasion. No partition theories have been offered regarding Philem, and by all initial considerations, it is a single and complete rhetorical speech or communicative act in a self-contained epistolary. Verses 1-3 form an inclusio with verses 23-25 with the repetition of key descriptive terms such as 'prisoner' (v. 1, 23), 'fellow-worker' (v. 1, 2, 24) and 'grace' (v. $3,25)$. There is a strong linguistic and semantic cohesion in the text. Statements, phrases and sometimes words in one section either anticipates or forms the basis for appeals to be made in other sections of the letter. These elements serve as a common thread weaving the major sections of the discourse together to give the discourse a holistic outlook to the listening audience. The rhetoric of the letter could be best appreciated when the sections, paragraphs, phrases, verses or punctuations are viewed as integrally connected. Hence, this exegesis treats Philem in its entirety as a rhetorical unit.

\section{ii. THE RHETORICAL SITUATION ${ }^{12}$ OF PHILEM}

Every Pauline letter is a situational literary piece occasioned by particular disturbing issues and addressed to a targeted audience who were directly affected by the situation. In this sense, Philem is a specific response to an exigency that needed an immediate response. The letter is informed by its historical-situatedness although the exact situation is shrouded in ambiguity. Consequently, four major divergent theories have been put out to explain the occasion and purpose of the letter. The traditional view posits:

\footnotetext{
4 By qualitative research, the researcher is concerned with a qualitative phenomenon within its natural setting to understand human behaviour and the reasons behind such behaviour. John W. Creswell, Research Design: Qualitative, Quantitative, and Mixed Methods Approaches (London, UK: Sage Publications Limited), 145 .

5 The term 'hermeneutics' comes from the Greek god Hermes, the messenger of the gods. The verb of his name, "hermenuein" means to interpret or to translate and the noun simply means interpretation. Hermes, the son of Zeus was responsible for transmitting messages from the Greek gods to the citizenry. His business was not merely to regurgitate what the gods had told him, but more importantly to decode the messages and make them understandable to the recipients, who unlike the gods, were mere mortals. He had to re-create or re-produce the meaning that would connect to his audience's history, culture and concepts in order to make sense of things Taking a clue from the activity Hermes performs, "hermeneutics" then is the act of transferring or bringing a message from source and making it comprehensible to the recipient(s) or audience. Anthony C. Thiselton, Hermeneutics: An introduction (Grand Rapids, MI: Eerdmans Publishing Company, 2009), 3-4.

6 Richard N. Longenecker, New Wine into Fresh Wineskins: Contextualising the Early Christian Confessions (Peabody, MA: Hendrickson, 1999$), 12$. Jeannine K. Brown, Scripture as Communication. Introducing Biblical Hermeneutics, (Grand Rapids, MI: Baker, 2007$), 33$.

8 Rhetorical criticism generally is the science of discovering the means by which a text persuades its audience. In other words, it is the study of the literary effectiveness of a text.

9 George A. Kennedy, New Testament interpretation through rhetorical criticism, 3. He describes it as "that quality in discourse by which a speaker or writer seeks to accomplish his purposes"

10 Danny Olinger, “A redemptive-historical consideration of Philemon," NWTS 12, no. 1 (1977): 23-32.

11 The researcher translated the original text from Barbara and Kurt Aland, Johannes Karavidopoulos, Carlo M. Martini, Bruce M. Metzger, ed., Novum Testamentum Graece, 28th edition (Stuttgart: Deutsche Bibelgesellschaft, 2012), 655-656.

12 The term 'rhetorical situation' was coined by Lloyd F. Bitzer to refer to "complex of persons, events, objects, and relations presenting an actual or potential exigence which can be completely or partially removed if discourse, introduced into the situation, can so constrain human decision or action as to bring about the significant modification of the exigence.” Lloyd F. Bitzer, "The rhetorical situation.” Philosophy and Rhetoric, 1 (1968): 7.
} 
Onesimus, a slave owned by Philemon, was 'unprofitable' (achrēston, v. 11) in the past and had fled his master (echōristhē, v. 15) after having robbed him (ëdikēsen, v. 18). Onesimus either voluntarily or accidentally fell in with the apostle Paul, who converted him to Christianity (v. 10). Paul, who had been the grateful recipient of Onesimus's past services (v. 13), now requests Philemon not only to forgive his formerly disobedient slave but to accept him as a brother in the Lord (v. 16). ${ }^{13}$

A score of modern commentators ${ }^{14}$ has interpreted Philem in the light of this theory because slaves seeking their freedom by running away from their masters were common in Paul's days. For instance, John D. Nordling ${ }^{15}$ draws on extrabiblical evidence to defend the hypothesis that Onesimus was a runaway slave who had robbed his master. The difficulty of the theory is that theft is nowhere explicitly stated in the letter. ${ }^{16}$ Another theory suggests that Onesimus had been sent by the church to offer assistance and perhaps financial aid to Paul but the slave overstayed. This made Paul write to implore the master not to punish the slave and further to request for Onesimus to be released from his obligation so that he might come to help him in evangelization. ${ }^{17}$ However, if Philemon or the church had sent Onesimus as their emissary, then it is hard to understand why Paul writes that passive verb of verse 15 which suggests that Onesimus left Philemon without the latter's consent. Another reconstruction of the situation behind Philem is the intercessory theory ${ }^{18}$ which argues that Onesimus, who has been in domestic trouble with his master left the house to seek the intervention of an Amicus Domini (friend of the master) in the hope that he might be restored peacefully to this former status in the master's household. Supporters ${ }^{19}$ of the theory contend that since Onesimus absconded from his master with the express intent of going to enlist Paul's service as a mediator in a domestic dispute between himself and his master, then he was not a fugitive as the traditional theory would want readers to believe. Whereas this theory explains much of the data in Philem, it is strange that there is a lack of any clear reference in the letter either to the wrong on Onesimus' part or remorse on Philemon's. The fourth and perhaps most tendentious hypothesis conjectures that Philem was occasioned by a disagreement between two biological Christian brothers - Philemon and Onesimus - where the former was treating the latter as if he were a slave. ${ }^{20}$ Allen Callahan claims that "nothing in the text conclusively indicate that Onesimus was ever the chattel of the letter's chief addressee and the problem that Paul sought to address in the letter was not that Onesimus was a real slave (for he was not), nor that Onesimus was not a blood brother to Philemon (for he was), but that Onesimus was not a beloved brother to Philemon." ${ }^{21}$ While Callahan's argument could at best be appreciated as an abolitionist biblical argument against proslavery advocates who appealed to the letter as "Pauline Mandate" for enslaving others, it is nevertheless highly inaccurate to think that Onesimus was not a slave in a literal way. To conjecture that Onesimus was not an actual slave in Paul's thinking denies the force of hōs doulon (as a slave) at verse 16 in the Greek text and hence Callahan strains the interpretation of this verse. The conjunction hōs cannot be twisted to give 'a contrary-to-fact nuance.' 22

The situation of Philem seems to have been this: Paul, now in prison in (probably) Ephesus, has fallen in with a runaway slave named Onesimus and converted him. The slave is being transported back to the legal master,

\footnotetext{
13 John D. Nordling, “Onesimus fugitivus. A defense of the runway slave hypothesis in Philemon.” JSNT, 41 (1991): 97-119. The runway slave hypothesis was first advanced by the Fourth-Century Church father, Chrysostom. See, John Chrysostom, "'Homilies of St John Chrysostom on the Epistle of St Paul the Apostle to Philemon," in A Select Library of the Nicene and Post-Nicene Fathers of the Christian Church, ed. Peter Schaff (New York: Christian Literature Company, 1889): 545-57. Margaret M. Mitchell, "John Chrysostom on Philemon: A Second Look," Harvard Theological Review 88 (1995): $135-48$.

14 John M. G. Barclay, "Paul, Philemon and the Dilemma of Christian Slave-Ownership." New Testament Studies 37 (1991): 161-86; Joseph A. Fitzmyer, The Letter to Philemon (Doubleday: New York, 2000); Peter Thomas O’Brien, Introductory Thanksgivings in the Letters of Paul (Leiden: Brill, 1977); Norman R. Petersen, Rediscovering Paul: Philemon and the Sociology of Paul's Narrative World (Philadelphia: Fortress Press, 1985).

15 Nordling, Onesimus fugitivus, 98.

16 Perhaps, the portrayal of Onesimus as runaway thief derives from common Greek and Roman tales of the 'crafty slave', portrayed in comedies, who stole from his master and either used that money to pay for his release or fled before he could be discovered.

17 Sara B. C. Winter, "Methodological Observations on a New Interpretation of Paul's Letter to Philemon." Union Seminary Quarterly Review 39 (1984): 203-212; Craig S. Wansink, Chained in Christ: The Experience and Rhetoric of Paul's Imprisonment (England: Sheffield Academic press, 1996), 179. Based on the description of him being "useless", and not being a believer, it seems unlikely that Philemon would have sent Onesimus on such an important errand to Paul. It is more likely, as Barclay concludes that Onesimus ran away After meeting Paul, Onesimus had converted to Christianity and become a source of companionship and service to Paul (vv. 11-12).

18 Peter Lampe, “Keine "Sklavenflucht” des Onesimus," Zeitschrift für die neutestamentliche Wissenschaft 76 (1985):135-37; Brian M. Rapske, “The Prisoner Paul in the Eyes of Onesimus," New Testament Studies 37 (1991): 187-203.

19 Peter Lampe first advanced the amicus domini theory and it was later supported Brian M. Rapske, 'The Prisoner Paul in the Eyes of Onesimus," New Testament Studies 37 (1991): 187-203; James D.G. Dunn, The Epistles to the Colossians and to Philemon (Carlisle: Paternoster Press, 1996); Bartchy, S. Scott, "Philemon, Epistle to," in ABD 5 (1992): 305-310.

20 The 'estranged brother' theory by Allen Dwight, Callahan, "Paul's Epistle to Philemon: Toward an Alternative Argumentum," Harvard Theological Review 86 (1993): 57-76; "John Chrysostom on Philemon: A Response to Margaret M. Mitchell," Harvard Theological Review 88 (1995):149-56; Embassy of Onesimus: The Letter of Paul to Philemon (Valley Forge, PA: Trinity Press International, 1997). For Allen Callahan, Onesimus was a mistreated genetic brother of Philemon.

21 Callahan, Embassy of Onesimus, 372.

22 To refer to Philemon and Onesimus as "estranged Christian brothers" openly contradicts the Greek text of Philem about Onesimus becoming converted through the instrumentality of Paul the prisoner because the verse 10 suggests that Onesimus might have not embraced the Christian faith before meeting Paul. See, Fitzmyer, The Letter to Philemon.
} 
accompanied by the present letter, thus stating that Paul has recently found the slave useful and wished to use him further in his ministry but he will not presume to keep him apart from Philemon's own free consent. Meanwhile, Philemon should welcome Onesimus back as a "brother" (vv. 16-17) and prepare Paul a guest room if he should soon arrive (v. 22). Apart from the fact that Paul expresses, quite obscurely, his confidence that Philemon will do "more" than he asks (v. 21), he makes no further request explicit. Not "manumission." Not anything.

The traditional hypothesis seems most plausible to the researcher. In the Greco-Roman culture of honour and shame, slave flight was an extreme act of insubordination to the master and usually, he would not hesitate to assert his full authority over the slave to restore or defend his honour. A fugitive slave was naturally anxious and afraid to face the anger of the dominus. Against this background, Philem is fashioned to intercede ${ }^{23}$ for a new relationship of brotherhood between an aggrieved master and the slave who had been alienated by social structures and by recent actions.

\section{iii. THE RHETORICAL CATEGORY OF PHILEM}

Among the three rhetorical genres, Philem is essentially deliberative rhetoric with slight forensic and epideictic nuances. ${ }^{24}$ In deliberative rhetoric, "the key is to demonstrate love or friendship, and to induce sympathy or goodwill, in order to dispose the hearer favourably to the merits of one's case." ${ }^{25}$ The argumentation of Philem invests in praising and requesting a line of action based on its expediency and beneficial nature. As would be shown shortly, Paul is purposefully persuading or moving Philemon, the prime addressee, and his household church to do something new - to make a difference. He establishes strong ethos with Philemon, the chief audience, and uses arguments that relate and resonate with the spectatorial assembled saints at the house. The message implores Philemon to acknowledge the expediency in extending hospitality to Onesimus and treat him with dignity. In other words, he demands Philemon to extend hospitality to the slave Onesimus because that is the most expedient quality demanded by Christian love ethic contrary to existing Greco-Roman slavery standards.

\section{iv. THE INVENTION, ARRANGEMENT AND STYLISTIC COMPONENTS OF PHILEM}

The way Paul invented his discourse could be gleaned from the arrangement of the various components of the text. Taken as a whole, Philem presents the following rhetorical structure: (a) epistolary prescript (vv. 1-3); (b) exordium (vv. 4-7) which is analogous to epistolary thanksgiving and prayer wish; (c) argumentative proof (vv. 8-16) and (d) peroratio (vv. 17-22) found in the body section of the letter; and (e) an epistolary postscript or final greetings (vv. 23-25).

\section{a) The prescript of Philem (vv. 1-3)}

The prescript does not only communicate the conventional information about the writer(s) and the recipient(s) but more importantly, it sets the tone for the rhetorical goal of the content that will follow. In the sender section, Paul emotionally identifies himself as desmios Christou Iessou (prisoner of Christ Jesus) with Timothy beside him (as co-sender) to set off his appeal on a note of empathy with Onesimus. ${ }^{26} \mathrm{He}$ deliberately makes his physical imprisonment an important backdrop to his entire appeal. As the letter unfolds, it becomes clearer that Paul's mentioning of his imprisonment was hard to go unnoticed: it was certainly going to induce emotional sympathy that would automatically influence his appeal for Onesimus. The apostle, although finds himself in a dangerous condition, not knowing what would happen to him the next hour, yet rises above his terrible condition to make an unparallel appeal for a frightened slave who would soon face the anger of his Domini.

The mentioning of Timothy as a co-sender could imply that the audience knows him and have some level of affection for him. By describing him as 'brother,' Paul is alluding to the trustworthiness of Timothy and the valuable services he renders to God (Phil 2:19-24). But more importantly, it indicates that Timothy knows about the issue at stake, and he lends his full support to Paul's appeal. In a similar vein, the mentioning of Apphia, Archippus and housechurch as co-hearers functioned to strengthen the persuasive force of the appeal that would be made in the body of the 1etter. ${ }^{27}$

${ }^{23}$ There is a 1st C.E. contemporary correspondence between Pliny the Younger and Sabinianus, whose freedman had fled to the former for intercession. Pliny's letter uses rhetorical expressions remarkably alike to that of Philem, even to the point of specifically reminding the recipient of the requester's authority, which will not be needed because the recipient will comply voluntarily. Pliny explicitly ask the master to exercise the stoic virtue of clemency, but there is not even one word that Paul uses to plea forgiveness for Onesimus. Instead, Paul appeals to Philemon in terms of Christian love and faith. For the full text of Pliny's letter, see Edward Lohse, Colossians and Philemon, (Philadelphia: Fortress Press, 1971), 196- 197.

24 Kennedy, New Testament interpretation through rhetorical criticism, 19.

25 Kennedy, New Testament interpretation through rhetorical criticism, 19-22; Forrester F. Church, "Rhetorical Structure and Design in Paul's Letter to Philemon," Harvard Theological Review 71 (1978): 17.

26 Paul's situation and legal position of a prisoner are close to those of a slave. Markus Barth and Helmut Blanke, The Letter to Philemon (Grand Rapids, MI: Eerdmans Publishing Co., 2000).

27 Though occasioned by a personal private matter involving a Christian master and his slave, Philem is a personal appeal in the public context of the housechurch. Paul deliberately sets his plea for Onesimus in the public space by broadening the audience in both the opening and closing sections. See, Clarice J. Martin, "The Rhetorical Function of Commercial Language in Paul's Letter to Philemon (Verse 18)," in Persuasive Artistry: Studies in New Testament Rhetoric in Honour of George A. Kennedy (JSNTSup, 50), ed. Duane F. Watson (London: JSOT Press, 1991), 32137. 
Philemon, the main recipient, is described as tō agapētō (our beloved brother, friend). This concept implies mutual love extended from one to the other in the ecclesia. The description indirectly prompts Philemon ${ }^{28}$ to remember that he belongs to a community founded on mutual love. He is a great benefactor to the "saints" and is considered a committed Christian in his charitable deeds. Paul's description of Philemon as tō agapètō projects the paterfamilias as someone who has lived true to his name by showing great hospitality to friends, family, and the church. Seen in this way, the adjective is strategically used by Paul to anticipate his main appeal in the body of the letter that the slave owner welcomes Onesimus back in the same agape (love) which characterizes the ecclesia. Philemon is also praised as sunergo $\bar{e} \bar{m} \bar{o} n^{29}$ (our fellow worker). The titles accorded Philemon by implication pull him deeper into the rhetorical circle Paul envisioned. Philemon is going to be put in a situation that would demand him to act as 'a beloved and coworker': He would be required to perform a disturbingly tough but befitting activity that would refresh the viscera of a person whose name he would not want to hear yet whose viscera has become interconnected with that of brother Paul, the imprisoned apostle of Christ.

Again, the inclusion of adelphē (a sister), Archippus (who is described as a systratiōtēs tō hèmōn, our fellowsoldier) and your house-church (oikou sou) as co-hearers gives the letter an added persuasive urge. It deliberately makes Paul's appeal a public matter ${ }^{30}$ read aloud in the presence of the mentioned addressees. The setting in which the letter was going to be heard would heighten the desired impact: it was calculated to exert considerable pressure on Philemon to protect his honour and reputation.

\section{b) The Exordium (vv. 4-7)}

In Greco-Roman oratory, the exordium seeks both to establish rapport with the audience, establish the author's ethos, and communicate a forecast of what is to follow. ${ }^{31}$ According to Aristotle, the attempt to appeal to the deeper emotions such as empathetic love and so to create pathos in the hearer is an attempt to put the hearer into a certain kind of receptive frame of mind. ${ }^{32}$ Paul uses praises to establish a trustworthy disposition and goodwill between himself and Philemon, the main addressee. He makes Philemon feels important and appreciated.

There is a complex and controversial case or exigency before Paul, one which has alienated the sympathy of the main addressee who was about to listen to the speech. At the very least, there is a serious breach of trust, a serious infraction of the law as well as a disregard of Philemon's social status. Thus, before Paul puts forward his main appeal, he must, from the onset, not only appease the injured paterfamilias but also anticipate the key-value terms upon which he would advance his arguments. This would make Philemon to be attentive, receptive, and well-disposed towards the rhetor and to lend an attentive ear to the rest of the discourse.

By declaring "I always remember you in my prayers," ${ }^{33}$ Paul is securing goodwill or trustworthy character from the addressee(s). In the ancient Greco-Roman world, expressing voluntary gratitude was a way of sustaining the mutual exchange of favours. The rhetor presents himself as someone who has personally benefited from Philemon's lovely gesture, Paul has a way of securing a trustworthy character from the addressee(s). He acknowledges in verse 5 that he constantly receives news about his faith and the love of Philemon but at the same time, he expresses the hope that Philemon's sharing in the faith may be oriented around the consciousness of every good thing that Christ is doing make among the saints. This carefully constructed prayer-wish was to broaden the horizon of Philemon's understanding to consider "every good thing" in Christ. ${ }^{34} \mathrm{He}$ further mentions his own profound affection of joy (chara) and encouragement or comfort (paraklesis) because Philemon's love has caused the splanchna (viscera) of the saints to

\footnotetext{
28 From its verbal root (philein, "love"), the Greek name Philēmōn probably meant kindness, affectionate, or worthy of love. Fitzmyer relates a Greek myth to buttress the meaning of this name. In the legendry myth, Zeus and Hermes disguised themselves and came down on earth to test the piety of human beings but they were refused hospitality by all but only a peasant couple, Philemon and Baucis received them. Impressed by this good treatment, the gods revealed their identity and directed Philemon and Baucis to climb a mountain to save themselves from imminent flooding that would destroy the land. Later Philemon and Baucis were made priest and priestess of the gods. It appears Paul is plausibly punning meaning of the name with the adjective, agapēthos. See Fitzmyer, Philemon, 84.

29 This is a dignified title used to describe personalities like Timothy (Romans 16:21; 1Thessalonians 3:2), Prisca and Aquila (Rom. 16:3), Titus (2 Corinthians 1:19, 1Thess. 3:2), Euodia and Syntyche (Philippians 4:2-3); Aristarchus, Mark, Demas and Luke (Philem. 24), Jesus Justus (Colossians 4:11) Epaphroditus (Phil. 2:25) who were making immensely contribution towards the spread of gospel and growth of the brotherhood.

30 Peterson, Rediscovering Paul, 99; Fitzmyer, Philemon, 81. It is harder to turn down a request made in public than one made in private. In the pubic, one's honour is at stake and the least thing one does will amount to shame. Paul deliberately couched the address in a public context so as to cajole Philemon to agree to the request of the letter before the public

31 Ben Witherington, The letters to Philemon, the Colossians and the Ephesians: A socio rhetorical commentary on the Captivity Epistles (Grand Rapids: Eerdmans, 2007), 28. The also exordium functions like an "overture in which each of the themes to be later heard in different, perhaps more specific context, is given an anticipatory hearing." See, John Knox, Philemon among the Letters of Paul: A New View of its place and importance (Nashville: Abingdon, 1963$), 4$.

32 Aristotle, Art of Rhetoric, trans. H. Rackham, LCL 73 (Cambridge: Harvard University Press, 1926). Appeal to the emotions may well reach a person at a level that pure logic will not, to demonstrate friendship and love for the hearer so as to induce goodwill in the hearer and make him inclined to act as requested.

33 If Paul were to deliver orally in person in the congregation, he would be looking straight at Philemon with everyone observing. The professional lector certainly maintained regular eye contact with Philemon as he was delivering the message of the appeal.

34 In Galatians 6:10, Paul tells Christians, "let us do good to all people." Also, in Ephesians 2:10, there is the expression "created in Christ Jesus to do good works."
} 
be refreshed (anapauō). ${ }^{35}$ Philemon is being depicted here not just as a person who loves but as a merciful person who attends to the innermost needs of the saints with great sensitivity.

In sum, verses 4-7 prepared Philemon in advance for a request by reminding him of his previous generosity exhibited towards all God's dedicated people. The rhetor Paul, fashioned admirable praise for the furtherance of the case by underscoring those qualities of Philemon upon which its outcome hinges. Having stimulated Philemon's emotions to render him biased in the desired direction, Paul proceeds to formulate the actual request of the appeal with both logical and emotive argumentative proofs.

\section{c) The Argumentative Proof (vv. 8-16)}

Indeed Philem 8-16 is the main body of the letter's deliberative appeal. The argumentative proof correlates with the epistolary body-opening (vv. 8-12) and body-middle (vv. 13-16). The rhetorical crescendo of the appeal builds up from statement to statement throughout the rest of the letter. Imagining the way into the household of Philemon, the particular spot where the dedicated people of God have gathered to hear the letter performed aloud, the current reader could visualise Onesimus, the letter courier and the lector standing there with all the authority of Paul.

In the preceding section, the rhetor eulogised praises and gratitude to Philemon for his love towards the saints. On the basis of that, he sets before Philemon a rhetorical exigency and appeals to him for love's sake to demonstrate that same love he had been commended for. The rhetor starts with a skilfully balanced appeal to his credible character and Philemon's empathic love, employing the literary device of tautologous parallelism:
8 So, although in Christ I am bold enough to command you to do what is proper,
9a instead I prefer to appeal to you out of love

9b I, Paul, an ambassador
$\mathbf{9 c}$ and now a prisoner too for
Christ Jesus,
$\mathbf{1 0 a} 1$ appeal to you on behalf of my child,
whose father I have become in my
imprisonment

With implicit reference to his apostolic authority, Paul states emphatically, echōn pollen parrēsian to anēkon ${ }^{36}$ (I could be bold, or I have strong boldness to order you [Philemon] to do what you ought to do). Just after drawing attention to his credible authority 'to command' (epitassein), he quickly refrains to beseech (parakalō) Philemon on empathy terms. In other words, he voluntarily lays aside his legitimate authority or unquestionable power en Christo and appeals to Philemon in "the most excellent way," the way of love in the presence of the gathered saints. He draws a sharp parallel between using 'authority to coerce' and 'appealing on the basis of love' and paradigmatically fashions his appeal on the Christian principles of love. ${ }^{37}$ The rhetor's decision to appeal by terms of love instead of by authority was a carefully planned rhetorical move because he had already extolled Philemon for his unparalleled reputation of love and faith.

Again, Paul uses the rhetorical device of antiphrasis ${ }^{38}$ in verses $9 \mathrm{~b}, 9 \mathrm{c}$ and verse $10 \mathrm{a}$ to reinforce the theme of love in the appeal. He deliberately relinquishes his power as both Christ's ambassador and now his prisoner to rely upon the voluntary acquiescence of Philemon to his request. In an actual sense, this was another persuasive move to establishing a stronger argument to reinforce the actual appeal.

At this stage of performing the letter (vv. 9b-10a), it is plausible the lector looked into the eyes of Philemon who in the same way looked at the reader and visualised Paul himself. ${ }^{39}$ This visualisation becomes more vivid in the v. 9b which reads: toioutos hōs Paulos nuni presbutēs nuni de kai desmios Christou Iēsou (none other than I Paul, an ambassador and now also as a prisoner of Christ Jesus). These words forcefully generate a visual image of the current status of Paul as the revered apostle of Jesus under legal bondage in a prison cell. Undoubtedly the visualisation of the condition of Paul evokes a feeling of respect and sympathy. ${ }^{40}$

It is only after the double-stated appeal that Paul finally introduces the name of the subject of the appeal in verse 10. But just before the name is mentioned, Paul prepares the ground tactfully by affectionately describing him as to emon teknon es tois desmois mou (my child, whom I have begotten in my chains). Here the kinship language, teknon

\footnotetext{
35 The verb anapauō suggests 'to cause someone to become physically refreshed as the result of resting from work.' Splanchna literally refers to human entrails, bowels, innards, where one's deepest or innermost feelings are located. It is a more emotive term than the common kardia.

36 Anékon is a substantival participle which carries the sense of "what is fitting or right/proper" or "the right thing," Fitzmyer, Philemon, 104.

37 Love characterizes the kind of faith by which a Christian must live. such love involves freedom from self-regard or selfishness and an outgoing affection for others, Phil 2:4; 1Cor. 13; Rom. 13:9. Fitzmyer, Philemon, 104.

38 Antiphrasis is an oratorical device where the orator openly abandons an apparently strong line of argument. Cicero writes, "I will not plead against you according to the rigour of the law, I will not press the point which I should perhaps be able to make good.” See, Cicero, De oratore and De partitione oratoria, trans. E. W. Sutton and H. Rackham. (Cambridge: Harvard University Press, 1965).

39 Scot McKnight, The letter to Philemon, NICNT (Grand Rapids, Michigan: Eerdmans Press, 2017 ), 80.

40 In no small way, the repetition of the verb parakelo serves as an amplification or appeal to pity. It functions to pull the heartstrings of Philemon not once, but twice. See, Church, Rhetorical Structure and Design in Paul's Letter to Philemon, 43.
} 
expresses not physical birth but a symbolic relationship as a consequence of Onesimus' conversion. He is not a pias (a boy) as having non-legal manhood but a teknon as a spiritual offspring. Onesimus ${ }^{41}$ has been catechised to the Christian faith through Paul's instrumentality. The suspension of Onesimus's name until this point is rhetorical. Paul works a $\operatorname{pun}^{42}$ on the name of Onesimus to reinforce his appeal. The punning - Onēsimon, who formerly was achrēston (useless) to you, but now has become euchrēston (useful) indeed, to you and me - establishes the motive of utility (utilitas) in the intrinsic usefulness of a human being. Philemon's consciousness is being awakened and broadened from seeing the slave with the inhumane secular mirror to seeing him in terms of the Christian worldview.

Some interpreters explain the punning to suggest that Onesimus became 'useless' either by running away or by having caused his master some financial damage. Sara Winter ${ }^{43}$ claims that Onesimus was 'useless' in the spiritual sense because he was non-Christian but now is 'useful' (spiritually) because he has transformed, and become born again in Christ through faith and baptism. In a different sense, Jennifer Glancy ${ }^{44}$ proposes that 'useless' and useful' just like 'disposable' are registers of utility language in the world of slaveowners. To infer from the popular proverbial saying at the time, 'a useless Phrygian slave becomes better by whipping,' the research argues that the punning reflects the perceptively entrenched stereotypical notion about (Phrygian) slaves at the time, not because of any perceived theft case or economic loss. Plainly, Paul is saying something like: "I have experienced Onesimus as a useful person and so I suppose you (in Christ) will see him as well". Thus, Paul wants Philemon to get the discernment that Onesimus' value transcends the secular notion of slaves as ironically unprofitable tools. He is intrinsically a useful being.

In verses 12-14, Paul builds the appeal with motives of honour. He skillfully demonstrates the virtue honour, and on the basis of it, demands Philemon to willingly reciprocate it exactly.

\section{2 ... I have sent back to you, this one who is my very own heart. \\ 131 would have preferred to keep him here with me, so that he might serve me on your behalf during my imprisonment for the gospel;}

\author{
$\mathbf{1 4}$ but without your consent I preferred to \\ do nothing so that the good you do might \\ not be by compulsion but come of your \\ own free will
}

In verse 12, Paul recognises the legitimacy of slavery (and ownership) by cooperating with legal authorities to send ${ }^{45}$ Onesimus to his legal owner. Unsure about how Philemon the master would react to the returned slave, Paul had to accompany the slave with this letter that it might evoke merciful treatment. The rhetor allows Philemon an opportunity to demonstrate a good deed exemplified by Paul himself. Onesimus has become Paul's child while in prison and Philemon - upon his partnership with an apostle - is been entreated to receive Onesimus as Paul's own inner self (v. 12). By identifying himself with Onesimus as his "very heart," Paul does not only generate empathetic feelings in Philemon but more importantly, he suggests to him to make the most excellent decision in the deliberative equivalence. ${ }^{46}$

In verse 13, Paul expresses the desiring thought or wish (eboulomēn) of retaining or to keeping (kaechein) Onesimus for profitable service ${ }^{47}$ during the apostle's imprisonment. There is an implicit request asking Philemon to return Onesimus back to him, as the master's deputy. However, in verse 14, Paul gently acknowledges the legal sovereignty of masters over their slaves and rather appeals to the free consent or will (gnōmē) of Philemon. He wants

\footnotetext{
41 The Greek name 'Onesimus' means 'useful'; it was a typical slave name in the region of Ephesus. Other common names such as karpos (fruitful), chresimos (useful), chrestos (good, profitable) were borne by contemporary slave names of Rome. These were socially constructed name chosen for slaves by their masters. The Greco-Roman society constructed slaves as inferior humans who deserved to be dominated, exploited and used to expand one's economy, honour and status. The text establishes that Onesimus was a slave of Philemon. The actual status of Onesimus in the house of Philemon is unknown. He could have been a cook, a household manager, a padedagogus for Philemon's son, an administrator or a sexual slave. Irrespective of any vital role Onesimus occupied in the household, he still remained pias (a boy), a social death with no right to ownership (even of his own will), to seek justice, or adventurous life. The rhetor knew the weight of Onesimus' offence. A mere mentioning of the slave's name might provoke the master's anger. Paul therefore "strategically avoided the name of Onesimus up to this point after he had fully presented the transformations that have taken effect in the slave's life.

42 This punning serves to transform Philemon's perspective about the slave.

43 Sara C. Winter, "Paul's Letter to Philemon," New Testament Studies, 33, (1987): 5.

44 Jennifer A. Glancy, “The Utility of an Apostle: On Philemon 11," Journal of Early Christian History, 5, no.1 ((2015): 79. A similar view was expressed earlier by Joseph A. Marchal, “The Usefulness of an Onesimus: The Sexual Use of Slaves and Paul's Letter to Philemon,” Journal of Biblical Literature 130, no. 4 (2001): 749-770. Marchal averred that punning characterization of Onesimus throws light on his sexual utility (chressis) as previously 'useless' or 'not-useful' but currently 'good-for-use,' 'well-used,' or even 'easy-to-use'. However, the broader context of the utility binary of achēston/euchēston in the text clearly shows that Paul is not implying that 'Onesimus is 'good-for-use' as a slave, and thus 'easy-to-use' sexually, for Philemon, for the community of holy ones, and also even for Paul himself.

45 The Greek anepemsa is an epistolary aorist. The basic meaning of anaempein is 'send up' or 'send back'

46 'It is as if Paul, embodied in the runaway slave, came to Philemon in person with his request to be treated kindly," says, Helmut Koester, Introduction to the New Testament: History and Literature of Early Christianity (Philadelphia: Fortress Press, 1982), 135. Splangchna is a strong and forceful concept which is used for the whole person which, in the depths of its emotional life, has experienced refreshment through comfort and love. The same graphic terminology used to describe Philemon's compassion and refreshment to others in verse 7 and intentionally speak of himself out of an intimate relationship with both.

47 The word diakoeo covers a spectrum of services ranging from household chores (Mk. 22:31; Acts 6: 6-11; 1Cor. 16:15) to gospel and church ministry (Col. $1: 7 ; 4: 7 ; 2$ Cor. $11: 23$; 1 Tim. $3: 8,12)$.
} 
him to cooperate out of his own desire instead of by way of necessity. In essence, Paul does not want Philemon's decision or choice to be forced or coerced (anankē), rather he wants Philemon's decision to be hekousion (voluntary). ${ }^{48}$ Verses 15-16 closes the probatio of the discourse with argumentative proof from supernatural providence. Paul invites Philemon to discern the unfolding event from a divine perspective. He tactfully refers to the separation of Onesimus with a theological passive to suggest that the initiative belonged to God. The 'parting' or 'separation' was an incidence that happened to Onesimus, rather than something he completely initiated. Thus, by the passive voice of echōristhe, ${ }^{49}$ Paul injects a hint of divine providence into the whole situation. The past of Onesimus (i.e., his temporary parting), present (i.e., his permanent return) and his future, as a whole, connote to God's hidden purpose. If Onesimus' flight happened for God's all-knowing purpose ${ }^{50}$ then Philemon must discern the will of God in the difficult situation before him.

The divine separation between Onesimus and Philemon was temporary (pros horan) but the new relationship will continue eternally (ainōnion). ${ }^{51}$ Far from implying that the slave has returned for eternal servitude, Paul is alluding to their common relationship as Christian brothers, who are related eternally that not even death can separate them..$^{52}$ Paul makes a plea that elevates the slave from the margins of the family to the family table.

Verse 16 brings Paul's plea to a climax. While the word doulos (a slave) appears only here, it should not be read apart from the preceding particle $h \bar{o} s$ (as), which usually introduced a subjective reality, and not just an objective description (in v.17, hōs is used with reference to Paul himself). Thus, as the expression "as a slave" is syntactically contrasted with "more than a slave, as a beloved brother" utilizing the conjunction alla (but). Philemon is ouketi (no longer) ${ }^{53}$ to regard Onesimus as though he was just a slave, rather as a beloved brother, regardless of whether the latter would remain a slave or become Philemon's freedman.

Indeed, in terms of social location or status, Onesimus is presently a slave but Paul persuades Philemon to 'accept him back' (apechien) 'no longer as a slave but more than a slave, as a beloved brother' (hōs doulon alla huper doulon, adephon agapēton). At the very least, Paul is seeking to get Philemon to recognize much more about Onesimus beyond the social status of slavery. ${ }^{54}$

There are varying opinions on the possible impending decision Philemon should take because of the vague request in verse 16. Edward Lohse ${ }^{55}$ and Nordling ${ }^{56}$ opine that Philemon should take back Onesimus, restore him to the household and allow him to do his job in a healthy environment. But Helmut Koester, Ernst Lohmeyer, and Joseph Fitzmyer ${ }^{57}$ interpret the words in verse 16 as an indication of Paul's desire for Onesimus to be freed or manumitted at once and be returned to Paul as a Christian to assist in mission work. The position of the second group of scholars is highly improbable in the immediate historical context of the discourse. On-the-spot-manumission of a fugitivus would have denigrated Philemon's reputation" considering that master-slave relationship was a key social component of the Greco-Roman world. To interpret the verse as Paul's expectation for Philemon as instant abolishment of master-slave relationship with Onesimus by manumission of the slave would seem anachronistic. In truth, neither the famous slave revolutions nor the stoic teachings in the Greco-Roman world envisaged the abolition of master-slave relationships. Richard A. Horsely ${ }^{58}$ correctly observes that slavery was such an essential part of the socio-economic and religiopolitical structures of the empire in such a complex manner that it was impossible to imagine a society without master-slave relationships. Paul deals with the pragmatics of the problem instead of outright emancipation of the slave. He works within the constraints of the circumstance in such a way that he would at the same time appear redemptive and culturally sensitive. Nevertheless, there is no clause in the discourse which forbids Philemon from liberating Onesimus from slavery. If the appeal is first and foremost not for the manumission of Onesimus, then how should Philemon act as a Christian towards his fugitivus servus who is now also a Christian? The imprecise expectation or demand of Paul is that Philemon should make some adjustments for Onesimus in the household. As a committed Christian master, Philemon should allow his secular and socio-economic relationship with Onesimus to be transformed by the Christian virtues of tenderness, mercy, love, justice, sacrifice, and respect. In short, he should make all the necessary adjustments for the

\footnotetext{
48 Fitzmyer, Philemon, 112, The good that humans do must come from them extemporaneously and of their own freewill and not because of any necessity or constraint. That is the essence of being human.

49 The verb means 'to divide or separate' and in the passive 'to separate more generally to be taken away or depart (Act 1:4; 18:1). It 'explains the act, not from its outset, iteration, travel, or result but as a whole,' McKnight, The letter to Philemon, 94.

50 It echoes the words of Joseph to his brothers in Egypt (Genesis 45:5, 50:20).

51 The adjective ainonion (forever or eternally) stand in sharp contrast to the temporal phrase pros höran (for an hour or a while).

52 Fitzmyer, Philemon, 114.

53 The "no longer" echoes John 15:15, "I no longer call you doulous ... I have called you friends.” Paul uses the "no longer" expression in Romans 14:15 to appeal to Christians to be considerate towards one another.

54 The phrase en sarki kai en kurio (in the flesh and in the Lord) in verse $16 \mathrm{~b}$ in turn both expands and qualifies the reality of the transformed relationship Paul is pleading for. This reality encompasses all domains of human existence.

55 Lohse, Colossians and Philemon, 199.

56 McKnight, The letter to Philemon, 102.

7 McKnight, The letter to Philemon, 102.

58 Richard A. Horsely, “A Critical Alternative to Recent Readings,” Slavery in Text and Interpretation (1998): 153-200.
} 
slave to experience what it meant to be accorded as a 'human being' in those times.

In the same verse (i.e., v. 16), Paul prioritizes the relationship of Onesimus to Philemon to furtherance the plea that Onesimus should indeed be loved by Philemon to a degree that surpasses Paul's own concern for the slave. The word used here, malista - a superlative form of mallon - means "very much, particularly, exceptionally. ${ }^{59}$ The fact that the slave has won Paul's affection should touch Philemon also to welcome him back in an exceeding Christian spirit. The combination of en sarki kai en kyriō appears only here in Paul's letters although the two parts are common enough separately. The term sarki (flesh) refers to the actual flesh which covers the bones of a body or the body itself or a person of flesh and blood. In a transferred sense, it can refer to human nature with its limitations. Here en sarki ${ }^{60}$ used of Onesimus expresses his fundamental human status apart from his condition as a slave; it is status common Onesimus shares with Paul and Philemon by virtue that they are all 'human beings,' while en kuriō describes his new status in Christ. Paul acknowledges this inalienable aspect of Onesimus's existence. Despite Onesimus' past and social status, he is transformed by a life of spiritual dedication and obligation en kyrio (in the Lord).

In both spheres of physical relationship (en sarki) and Christian relationship (en kyriō), Onesimus is a useful being much appreciated by Paul. In the salutation formulae, Paul greeted Philemon as agapeton and now he beseeches Philemon to regard Onesimus adephon agapeton (beloved brother). The slave has become one of the saints because he has embraced the gospel. Like Philemon himself and the gathered audience, Onesimus is an adopted child of God through baptism (Gal. 4:5); thus, he must be welcomed to the Lord's table to share with everyone the holy kiss of peace. Paul has placed before Philemon the advantages he would accrue if he (Philemon) accepts Onesimus back. Likewise, he would show him the losses or disadvantages the latter would suffer if he insists on punishing Onesimus or refuse to receive him benevolently.

Although Paul has not made his request explicitly clear; he has hinted his expectation in his description of Onesimus in the proof. This constructs a climax for the audience. So, what does Paul actually want Philemon to do? In the peroratio section, Paul imperatively presses Philemon to undertake advantageous (un)specified activities.

\section{d) The peroratio (vv. 17-22)}

The peroratio serves as a restatement of the proof, as Quintilian writes, "it is the peroration, if anywhere, that we must let loose the whole torrent of our eloquence" ${ }^{\prime 1}$ Paul recapitulates his appeal (v. 17), he intensifies it (vv. 18-19), he sets Philemon in an emotional frame of mind (v. 20); and he requests for an ostensible favour (v. 22). Paul's use of the indicative imperatives, proslambou (welcome/accept) in verse 17, elloga (charge) in verse 18, and anapauson (refresh) in verse 20 place the force of the argument primarily on Paul's utmost concern with Onesimus' welfare.

At the onset of the discourse, in the exordium, Paul has expressed the prayer wish that the sharing (koinonia) of Philemon's faith becomes effective. Now at the peroratio, he demands Philemon to demonstrate his sense of effective partnership (koinonia) by receiving Onesimus as if he were welcoming Paul himself. Thus, the requests in verses 17-22 establish the significance of transforming the master-slave relationship. The request to Philemon seeks to redefine the values of Greco-Roman slavery in Philemon's household around the Christian values located in Christ.

The antecedent statement of verse $17 \mathrm{a}, e i^{62}$ sun me echeis koinōnon (if you hold me dearly as your fellow partner) establishes an irrefutable clause for Paul to get his appeal through. Paul premises his main appeal on the assumption of the mutually reciprocating life of love, fellowship and reconciliation in the ministry enterprise (or kingdom business) in Christ. They are now koinōnoi ${ }^{63}$ (fellows/partners) who share common obligations and opportunities in a new socio-ecclesial reality en christō.

Verse $17 \mathrm{~b}$ is the consequent statement that launches the actual appeal. Here, the apodosis of the conditional statement concludes with the imperative prolambou. ${ }^{64}$ The emphatic pronoun eme (me) stresses that Philemon should not only welcome Onesimus, but he should receive him as if it were Paul himself standing directly before him. As an ambassador of Christ for transformation between God and humans and between humans and humans in the ekklesia, Paul invites his partner (koinōnos) to prove himself by participating in the transformation agenda for Onesimus, first by

\footnotetext{
59 Fitzmyer, Philemon, 115.

${ }^{60}$ From the phrase, "in the flesh," Callahan and others claim that Philemon and Onesimus are biological brothers. However, such interpretation is less convincing in view of the plain use of 'doulos' to designate Onesimus in the same verse.

${ }^{61}$ Quintilian, Intitutio Oratoria, trans. H. E. Butler, LCL. (Cambridge: Harvard university press, 1920), 52.

62 The conjunction $e i$ (if) with the indicative expresses a simple but implicative condition.

${ }_{63}$ The noun koinōnos denotes "one who takes part in something with someone," for instance in business pursuit or commercial endeavour. It means one who share your life and has a common interest. Here, Paul is referring to the bond of (spiritual) friendship that exists among believers of a common faith.

${ }^{64}$ It is the first expression of a direct command to Philemon to welcome Onesimus as the virtual Paul. The word proslambaō is the middle voice used of God or Christ receiving believers and of Christians to receive one another. Paul exhorts the Romans that oi dunatoi (the strong) in faith to welcome (prolambanō) ta asthenomata (the weak) in faith because God has received both (Rom. 14:1, 3; 15:7). The natives of Malta showed unusual kindness to Paul and the shipmates; 'they kindled a fired and welcomed (proselabonto) all of us' (Acts 28:2). This significantly points to the unity of Christians in Christ (Gal. 3:27-28). See, Fitzmyer, Philemon, 116.
} 
receiving him in an undeserving manner. ${ }^{65}$

Paul's conditional clause in verse 18 is a tactful way of establishing the prima facie that the 'flight' itself constitutes an offence or financial loss to a master ${ }^{66}$ Employing an amplification device of anticipation, ${ }^{67}$ Paul offers to reimburse Philemon for any wrong deed or debt Onesimus may have caused. He commands (elloga) Philemon to reckon the debt to his own account. The aorist tense edikesen (wronged) is contrasted by the present tense ophelei (owes) to imply that there was a singular offence in the past with a continuous grievance in the present as a result of that wrong. ${ }^{68}$

In verse 19a, Paul gives a written acknowledgement of the debt owed to Philemon. The phrase te emē cheri dramatically indicates that Paul took up the pen from his amanuensis to write these words to assure Philemon that he (Paul) will pay (apotisō) for any damages he (Philemon) has suffered because of Onesimus. This also underscores how serious Paul takes the matter and this indicates that the letter is not a fabrication.

However, Paul appends his 'I OWE YOU' note in verse 19 with a counter statement. Utilizing this paradoxical tact of 'passing over,' Paul actually mentions what he does not want to mention. ${ }^{69}$ Paul transforms Philemon's status from creditor to debtor and thereby puts him under an infinite moral obligation to grant Paul's requests. But the question is: In what sense does Philemon "owe" Paul his "very self?" What is in view here is the debt of gratitude and obligation that come with one's conversion and eternal life in Christ. ${ }^{70}$ Philemon became a Christian through the instrumentality of Paul's evangelization and catechism. From that angle, Philemon is indebted to his spiritual father because his debt is far bigger than what Onesimus might owe him. Comparing the material debt that Onesimus may owe Philemon with the spiritual debt that Philemon does owe Paul, it is a fairer deal for Philemon to comply with Paul's terms of entreaty. The rhetor has skillfully and masterfully employed commercial language to formulate a very convincing and practicable case to re-align the audience's will to his own.

Having charged Philemon to transfer Onesimus' debt to him with the strong assurance that he will settle any debt, he follows up immediately with a subtle prayer wish at verse 20 . This prayer wish is appended with a mild imperative, anapauson mou ta splanchna (refresh my heart!) en christo..$^{71}$ Euphemistically, Onesimus is the splanchna of Paul, and it is en Christō kyriō realm Philemon is being implored to consider Paul's appeal and respond to it. The Kyrios demands that all Christians are to be one en Christō and deal with each other in an atmosphere of love, forbearance, and reconciliation. The implied nature of Paul's appeal could be deductively represented as shown below. ${ }^{72}$

Premise 1: Philemon is widely heard of (known) as someone with the virtue of refreshing God's people (v. 7).

Premise 2: Onesimus stands before Philemon as Paul's very own viscera; he also become a member of God's people (v. 12)

Conclusion: It is therefore imperative for Philemon to [voluntarily] refresh the viscera of Onesimus, the literal incarnation of Paul (v. 20).

It is "in the Lord" and "in Christ" where all this fellowship is to be located. ${ }^{73}$ What would bring rest (i.e., refreshment) to the viscera of Paul is when Philemon re-orients himself towards Onesimus and relates with him in a spirit of kindness, respect, sensitivity and love to open enough ways for him to maximize his humanness in all facets of life. Paul leaves these practical applications of the letter to Philemon's own conscience and judgement.

${ }_{65}$ An emissary or envoy represents the sender party. Thus, to welcome Onesimus is to receive Paul: conversely, to turn Onesimus away is to reject Paul himself.

${ }_{66}$ Ryan Lokkesmoe, "Finding Onesimus: Recovering the Story of a First-Century Fugitive Slave" (Electronic Theses and Dissertations, 2015), 46. Slaves like Onesimus were conventionally considered thieves of themselves and the value of their ongoing services when they ran from their masters."

${ }^{67}$ By this device, a rhetor perceives the objections that could be advanced against his argument and sweep them aside. He writes that he will make restitution for whatever Philemon has lost as a result of Onesimus' flight.

68 Terms such as adikein (to 'wrong' someone), opheilein (to owe) and ellogein (to charge to someone's account) are commercial and juridical languages employed by Paul to take Philemon's focus off of Onesimus, and place it squarely on himself.

69 The rhetor is seen to be relying on paralipsis, a figure of speech that allows a speaker to address a subject that he/she outwardly claims, does not need to be addressed. I could mention that you owe me your life, and I won't, but I have gone ahead and said it. Now I would like you to factor this into your decision in welcoming back Onesimus. See, McKnight, The letter to Philemon, 105-106.

70 Paul has willingly catechised Philemon in the faith, and so Philemon owes it to him to willingly share with him every earthly blessing. Thus, the words in verse $19 \mathrm{~b}$ imply the very common duty that a gift imposes on the one who received the gift - the duty to willingly respond in kind, in gratitude and reciprocal munificence. See, Rom. 15:27; Gillian Feeley-Harnik, "Is Historical Anthropology Possible? The Case of the Runaway Slave," in Humanizing America's Iconic Book, eds. Gene M. Tucker and Douglas A. Knight (California: Scholars Press, 1982), 95-126.

71 It is significant to notice that, here Paul employs the same term (i.e., splanchna) he used in verse 7 where he praised God because Philemon has refreshed the hearts of the holy people.

72 Forrester Church also observes that the three-fold repetition of the term splanchna taken together constitutes a syllogistic argument that is itself the touchstone of Paul's appeal. She formulated her insightful argument this way: 'If Philemon refreshes the hearts of the saints (v7); and, if Onesimus is Saint Paul's very own heart (v. 12); then, to refresh Paul's very heart, Philemon must refresh Onesimus (v. 20). See, Forrester Church, Rhetorical Structure and Design, 24.

${ }_{73}$ Some interpreters have argued that the benefits Paul is seeking were a formal request for Onesimus to be sent back to serve with him in missionary work. Others also think that Paul [in his capacity as amicus domini] is pleading forgiveness and reconciliation for Onesimus and his eventual release from slavery. Each of these interpretations is valid depending on one's hypothesis on why the separation occurred. The researcher's argument is that the prime 'benefit' and 'refreshment' Paul is demanding from Philemon is a transformation in the social dealings between the powerful, the dominus and the powerless, the slave. 
Having made his argument for Onesimus, Paul goes further on to place full confidence ${ }^{74}$ in Philemon's obedience and goodwill. The Greek expression in verse 21 a could be rendered as "I, confident as I am in your compliance, write to you." The perfect participle, pepoithōs ${ }^{75}$ makes Paul's confidence more vivid to Philemon. It expresses Paul's confidence (that is grounded in Christ) that Philemon will surely acquiesce to his request in the spirit in which that request is placed, due to Philemon's generous character and conduct. The emotions behind this expression function to undergird the letter's request by creating a sense of obligation through praise. It is a positive reinforcement strategy intended to elicit more of the good deeds and obedience ${ }^{76}$ Philemon has displayed in the past.

In verse 21, Paul drops another ambiguous challenge to Philemon: "you will do even more than I request" without spelling out what he means by "more." Most interpreters think that if the ambiguous "more" in verse 16 is less likely a plea or hint for legal liberation of Onesimus, then the "more" in verse 21, albeit its vagueness, is plausibly implying manumission. ${ }^{77}$ What is clear however is that the "more than I say" gives room for Philemon to treat Onesimus as a brother by welcoming him home and transforming the household relationship to reflect the encompassing unity in Christ which transcends mundane social boundaries among believers. ${ }^{78}$

Paul deliberately wraps up with a note of future visit to Colossae and to stay in Philemon's household immediately after he is released from prison. ${ }^{79} \mathrm{He}$ imperatively asks Philemon to have a guest room prepared in advance. This visit would allow Paul to see how Philemon reacted to the message of the letter. As Lohse puts it, for he will come and see for himself how things have gone. ${ }^{80}$ Thus, the request for xenia ${ }^{81}$ and the announcement of apostolic parousia function as negative reinforcers or indirect threat precautioning Philemon in advance of any unchristian thing he intends to do regarding his slave. With these final requests, Paul concludes the peroration of the entire discourse in a touching manner.

\section{e) The Postscript section (vv. 23-25)}

Just as in the opening formula Paul acknowledges the co-hearers, so does he include the greetings of five people. ${ }^{82}$ These greetings, in addition to the courtesy involved, also are intended to bring some further pressure on Philemon. ${ }^{83}$ The sensitive situation in Philemon's household is not a private matter that concerns him alone. How Philemon handles it would have a far-reaching implication on both Christians and non-Christians in the community. The mentioning of the "holy ones" in the final benediction and the plural "you" (sou) suggest clearly that the letter was to be delivered at a time when the church had assembled in Philemon's house. Everybody would be around to hear the reading of the letter and expect how Philemon would react to it, whether he will honour the request of the apostle by taking Onesimus to his side, or he would punish him. Such a setting and opportune time certainly added extra influence/persuasion on Philemon to grant 'even more than' what Paul has asked for. How can the summative effect of Paul's intercessory message to Philemon be judged, taking a holistic view of all the rhetorical acrobatics contained therein? This question is attempted in the subsequent section.

\section{v. EVALUATING THE EFFECTIVENESS OF PHILEM}

The efficacy of a persuasive speech depends on factors beyond the words of the dialogue. For instance, the readiness of the audience to accept a new view, the body language or posture of the speaker, and the social environment in which the

\footnotetext{
74 Quintilian, Intitutio Oratoria, 82, a rhetor emphasises his confidence in the integrity of the audience and justice of the cause, he maximises persuasion on the audience who may have special reasons for being hostile or ill-disposed to the cause one is advancing. Expression of confidence usually tends to serve a persuasive purpose.

75 This perfect tense is frequently employed by Paul to express his firm confidence in his audience (2: Cor. 2:3; Gal. 5:10; Phil. 1:6; 25). From the verb peitho, it used with a present meaning as "lean on, put one's confidence in, trust in." By way of praising Philemon in advance with the confidence formula, Paul was actually persuading and obligating him to carry out his requests.

76 The word hupakoe is often used by Paul to express 'commitment or obedience of Christian faith' (Rom 1:5; 16:26) or response to apostolic authority (2Cor. $7: 15 ; 10: 5-6$ ). It is less likely that Paul is asserting confidence in his own authority (as an apostle) since he explicitly declines in verse 8 to do so; rather he is referring to his firm trust in Christ. The absence of a direct object to hupakoe plausibly denotes that Paul is asserting his confidence in Philemon's religious commitment to Christ (Gal. 6:2).

77 Norman R. Petersen, Rediscovering Paul, 97, contends that the "even more" presumably required Philemon to synchronize the legal aspect of his worldly relationship with Onesimus with the social structural ground of their new churchly relationship by freeing Onesimus. Similarly, Nicholas T. Wright, The Epistles of Paul to the Colossians and Philemon (Leicester: Intervarsity Press, 1986); Murray J. Harris, Slave of Christ: A New Testament Metaphor for Total Devotion to Christ (Leicester: Apollos, 1999), 66; and Douglas I. Moo, The Letters to the Colossians and to Philemon, (Norton Street, Nottingham: Apollos, 2008), 435 make inference from Colossians to support the view that Philemon understood the "more" as Paul's demand for the legal liberation of Onesimus to become a fellow worker of Paul (Col. 4:7-9).

78 Gal. 3:28; 1Cor. 12:13; Col. 3:11.

79 Verse 22 sounds like a digression than a continuation of the appeal. However, and more correctly, the verse lends a certain emphasis to the appeal for Onesimus.; Lohse, Colossians and Philemon, 206.

80 Lohse, Colossians and Philemon, 206.

81 The term xenia (guest room) appears only twice in the NT (Philem. 22; Acts 28:23). It takes on the sense of 'hospitality' and the provision of a room which Paul needed during his visits to the churches.

82 Epaphras, Mark, Aristarchus, Demas and Luke know about the controversial domestic issue and are waiting for Philemon's reaction.

83 Moo, The letters to the Colossians and to Philemon, 439.
} 
speech is given can all shape the success of a rhetorical speech. Objectively, the question of whether the letter succeeded in influencing Philemon to receive Onesimus favourably cannot be answered with adequate historical proofs. However, the very fact that Philem survived and made it into the canon of Christian scriptures suggests strongly that Philemon acquiesced to Paul's petition. Having been composed with deliberative intents and conventions, the letter, from the standpoint of the same convention, should be effectively persuasive to its audience. Certainly, the need for him to avoid social shame pressed heavily on him. ${ }^{84}$ Paul managed to place Philemon in a position in which granting the plea will be the only way to maintain an honourable partnership with Paul and with saints.

At a minimum, this may imply that Philemon received Onesimus with considerate compassion and love, without any vindictiveness. At a maximum, it may connote that Philemon freed Onesimus as a result of Paul's letter. Church tradition has it that there was a 2nd Century C. E. bishop of Ephesus known by the name, Onesimus. Ignatius mentioned this Onesimus in a letter he wrote to the Ephesians sometime in the middle of Trajan's reign (98-117 CE). In that letter, Ignatius wrote:

Since, therefore, I have received in God's name your whole congregation in the person of Onesimus, a man of inexpressible love who is also your earthly bishop, I pray that you will love him in accordance with the standard set by Jesus Christ and that all of you will be like him. ${ }^{85}$

It is uncertain if this Onesimus is the same Onesimus who is the subject of Paul's appeal in Philem. For Paul wrote Philem in the early 60's C.E., Onesimus would have had to be quite young at the time of his flight, and relatively old at the time of Ignatius' writing to be the same person. What is plausible, nevertheless, is that Ignatius intentionally alluded to Philem in this text. When he described Onesimus to the Ephesians as "earthly bishop," he employed peerase en sarki episkopo (i.e., your bishop "in the flesh"). This is a pragmatic contextualisation of the crucial verse 16 in Philem, in which Paul exhorts Philemon to receive Onesimus back as a beloved brother "both in the flesh and in the Lord" (en sarki kai en kuriō). If the same figure in Philem ultimately became the bishop of Ephesus, this usage of en sarki was Ignatius' way of ingeniously linking him to that letter which had become significant in Christian communities. Whether or not the 2nd Century bishop of Ephesus was the Onesimus of Philem, it is still noteworthy that a man with the slave name Onesimus climbed up to become the bishop of a metropolitan city like Ephesus. This suggests the persuasive plea in Philem was truly revolutionary in both its primary and subsequent contexts.

In a cultural context that conceptualised slaves as fitting objects of domination - a place where runaway slaves were usually executed or penalised cruelly - Paul advocated for counter-cultural grace. He urged Philemon to perceive and treat Onesimus as a brother in Christ instead of a common slave. He allowed the circle of listeners on both ends of that letter to hear the message that their sacred identity as Christians surpassed any other social identifier and barrier between social statuses. Thus, Philem was Galatians 3:26-28 in action. Paul was not in charge of the political powers of his world; he could not all alone uproot the controversially entrenched institution of slavery. The ecclesial power he did have, however, was to cast a new vision for what the Christian community should look like, and encourage Christ-followers like Philemon and Onesimus to live in counter-cultural harmony.

\section{REFLECTIONS FOR MASTER-SLAVE RELATIONSHIP IN CHRISTIAN HOUSEHOLDS}

Justin Ukpong ${ }^{86}$ calls on critical readers of the Bible in the African context to actualize the theological sense of the read text in today's context so as "to forge integration between faith and life and engender commitment to personal and societal transformation." Interpretation of scripture is pursued first and foremost for the transformation of human society. Africans most of the time would like to see biblical interpretation as a living exercise that must come into actual operation in their day-to-day experiences in their lives. ${ }^{87}$ Even though both Christian parents, maids and fictive children may put different meanings to the text in their unique contexts, the following transformative reflections present an imperative 'call to action' for the Ghanaian parents or employers in Christian households.

Philem conveys a resounding exhortation to Christian parents and employers about the need to prioritise the welfare and spirituality of servants, maids and fictive children in one's household. The quality of the existing relationship between the Christian master and his/her subordinate(s) in the domestic contexts speaks volumes about the master's regard for core Christian values. The Christian master must not exploit the worth of their domestic workers in pursuit of unjust economic interests or comfort. In its primary context, the text gives considerable respect for the social

\footnotetext{
84 Moo, The letters to the Colossians and to Philemon, 440; David M. Russell, "The Strategy of a First-Century Appeals Letter: A Discourse Reading of Paul's Epistle to Philemon," Journal of Translation and Textlinguistics 11 (1998): 1-25; Roy R. Jeal, Exploring Philemon: Freedom, brotherhood and partnership in the new society (Atlanta: SBL Press, 2015), 153. When one visualises the occasion of the first performance of the letter, - what actually took place when the letter was delivered to, not only Philemon, but the Christian community gathered in his house; how the lector animated Paul's request; and the atmosphere in the room where Philemon was now presented with the slave, the latter seeking mercy, with the gathered saints looking on at the response of the former, - it can be assumed to a large extend that Philem achieved its desired outcome.

85 Michael W. Holmes, The Apostolic Fathers: Greek texts and English Translations (Grand Rapids, Mich.: Baker Books, 1999),

86 Justin Ukpong, "Developments in Biblical Interpretation in Africa: Historical and Hermeneutical Directions," in The Bible in Africa: Transactions, Trajectories and Trends, eds. G. O. West and M. Dube (Leiden: E. J. Brill, 2000), 24.

87 Eric N. B. Anum, “Exploring Religious and Ethnic Boundaries: A Contextual Bible Study of Matthew 5:13-20,” Journal of African Biblical Studies 2(2009):54.
} 
arrangement of the 1st Century Greco-Roman cultural milieu regarding economic and domestic rights of ownership, yet it states unequivocally that the Christian master should not be vindictive and wicked towards the slave. The Christian parent ought to discern appropriate ways of meeting the psycho-social and spiritual needs of the fictive child, maid, or servants at all times, especially when there is a dilemma, like the one Philemon was confronted within the community of Colossae. Domestic activities and intercourses should be anchored on Christian beliefs, values and principles such as respect for one another, love, forgiveness, forbearance, encouragement, gentle rebuke and corrections, empathy, feeling of acceptance, sharing or fellowshipping, reconciliation and opportunities for enhancing one's talents. Christian maids or fictive children, despite weaknesses in character or habit, should more loved and encouraged; less traumatized and abused.

Every human person by nature has some innate desire to connect or identify his/her 'soul' with a higher being or nature to achieve meaning in life. Growth in spirituality provides strength and emotional endurance to face life's challenges. All too often, some masters overlook the spiritual development of their servants and maids. Paul's plea that Onesimus should be welcomed as a 'brother' implies the slave was to be received into Church and allowed to participate in fellowshipping: the communal feast, the Lord's supper, listening to scriptures, praising and worshipping together. The deduction for modern-day Christian parents in the Ghanaian context is that they should provide a supportive environment for these less privileged people in their household to acquire education, skills and values for life.

Again, the letter gives insights into 'Christian ways' of handling inevitable dilemmas or challenges associated with master-slave relationships. There is a reflection on reconciliation and clemency. Meaningful fellowship between Christian parents and their maids or fictive children can only thrive in an environment of forgiveness. It takes the maturing spirit of clemency not just to 'put the past behind' but to also 'relate in the present' without any recourse to past mistakes. There is a strong call on the Christian parent to 'let go' of the pain, financial loss, frustrations, and troubles caused by servants and fictive children. The temptation to turn away disloyal slaves should be resisted. Instead, the master should focus on discerning the good thing to do for the Lord in every controversial situation the fictive children or maids put them.

Again, the virtue of hospitality, love, forgiveness, and restoration must be considered when addressing dilemmatic situations involving maids and fictive children. It is assumed Philemon acquiesced to Paul's plea and reinstated Onesimus. This implies that he generously forgave the slave without subjecting his infidel conducts to the rigorousness of Greco-Roman slave laws. He consolidated his Christian honour before the gathered congregants at his house by doing what was considered 'shameful' in Greco-Roman judgement: to welcome a notorious slave with a kind of hospitality reserved for those who have proven themselves worthy of it either by birth or accomplishments.' Such a supreme Christian practice must be paradigmatic to contemporary Christian parents. One must not compromise on his/ her Christian honour and identity by responding to difficult domestic matters 'unchristianly.'

In the Christian worldview, true freedom begins with receiving the message of Christ and allowing it to find the truest expression in one's life. The catechism Onesimus received from Paul set the slave free from all earthly anxieties - manumission, wealth, power, status, etc. The Christian faith equipped him with spiritual resources such as hope, encouragement and emotional strength to cope and eventually triumph over his earthly conditions. Fictive children and maids must learn from the good sides of Onesimus. They must embrace the gospel and develop endurance, hope, tenacity, positive self-concept and faithfulness towards their heavenly Lord. This commitment to God would produce in them spiritual strength and true freedom as well as earthly transformations. Genuine service to God and one's earthly masters yield unimaginable favour and upward growth. Tradition has it that Onesimus' dedicated service to both the Lord in heaven and legal master on earth following his conversion yielded him eventual manumission, honour and eternal identity in the Christian history and tradition.

\section{CONCLUSION}

The exegetical reading has sought to establish the persuasiveness nature and intents of Philem. Rhetorical criticism has given deeper insights into how Paul adapted Greco-Roman conventions of oratory to fashion his appeal for Onesimus. By putting Philemon strategically in an accountable position before the Christians gathering in the house-church, Paul cleverly relativized the cultural expectation of the paterfamilias, and paved ways for Onesimus' welfare, spirituality, reconciliation and social progress to thrive. Though Paul did not oppose the institution of slavery directly, he reframed the master-slave relationship between Philemon and Onesimus according to Christ's lordship and radically subverted the core of slavery from within. It would have been uneasy for a Roman paterfamilias to treat a slave as a brother. One can therefore imagine how radical and subversive it would have been for Philemon to welcome and treat Onesimus, his runaway slave, as a beloved brother. Paul's deliberative goal was to persuade Philemon to simply act out his faithrelationship in Christ by accepting Onesimus as a Christian brother in every sense of it. 
The message of Philem humanizes master-slave relationships in domestic contexts. It displaced Caesarcentric values characterised by dominance, exploitative motives and cruelty. In place of it, Philem has sowed Christocentric values which emphasise the dignity of all persons, brotherhood, and sensitivity to the plights of the weak and marginalised. Indeed, the transformative character of Philem has played crucial roles in pursuits which eventually split the rocks of slavery in times past. Even more importantly, Philem continues to provide Christians with a solid message that could be sowed into social struggles confronting contemporary communities - child slavery and exploitation, serfdom, displaced/stranded refugees and immigrants, human trafficking and other forms of complexities facing fictive children and parents in the household.

\section{ABOUT AUTHOR}

Maxwell Kojo Tsibu is a $\mathrm{PhD}$ candidate at the Department of Religion and Human Values. He holds B.Ed. and Master of Philosophy degrees from the same Department at the University of Cape Coast (UCC). He is a Tutor at the Methodist College of Education, Akyem Asene-Aboabo, Oda- Eastern Region - Ghana.

\section{BIBLIOGRAPHY}

Aland, Barbara and Kurt, Johannes Karavidopoulos, Carlo M. Martini, Bruce M. Metzger, eds. Novum Testamentum Graece, 28th edition. Stuttgart: Deutsche Bibelgesellschaft, 2012.

Anum, Eric N. B. "Exploring Religious and Ethnic Boundaries: A Contextual Bible Study of Matthew 5:13-20." Journal of African Biblical Studies 2 (2009): 54.

Aristotle. Art of Rhetoric. Translated by H. Rackham, LCL 73. Cambridge: Harvard University Press.

Barclay, John M. G. "Paul, Philemon and the Dilemma of Christian Slave-Ownership." New Testament Studies 37 (1991): 161-86.

Barth, Markus and Helmut Blanke, The Letter to Philemon. Grand Rapids, MI: Eerdmans Publishing Co., 2000.

Bitzer, Lloyd F. "The rhetorical situation." Philosophy and Rhetoric, 1 (1968): 7.

Brown, K. Jeannine. Scripture as Communication. Introducing Biblical Hermeneutics. Grand Rapids, MI: Baker, 2007. Callahan, Allen Dwight. "John Chrysostom on Philemon: A Response to Margaret M. Mitchell." Harvard Theological Review 88 (1995):149-56.

"Paul's Epistle to Philemon: Toward an Alternative Argumentum." Harvard Theological Review 86 (1993): 57-76.

. Embassy of Onesimus: The Letter of Paul to Philemon. Valley Forge, PA: Trinity Press International, 1997.

Chrysostom, John. "Homilies of St John Chrysostom on the Epistle of St Paul the Apostle to Philemon." In A Select Library of the Nicene and Post-Nicene Fathers of the Christian Church, edited by Peter Schaff, 545-57. New York: Christian Literature Company, 1889.

Church, Forrester F. "Rhetorical Structure and Design in Paul's Letter to Philemon." Harvard Theological Review 71 (1978): 17.

Cicero. De Oratore and De Partitione Oratoria. Translated by E. W. Sutton and H. Rackham.Cambridge: Harvard University Press, 1965.

Creswell, John W. Research Design: Qualitative, Quantitative, and Mixed Methods Approaches. London, UK: Sage Publications Limited.

Dunn, James D. G. The Epistles to the Colossians and to Philemon. Carlisle: Paternoster Press, 1996.

Feeley-Harnik, Gillian. "Is Historical Anthropology Possible? The Case of the Runaway Slave." In Humanizing America's Iconic Book, edited by Gene M. Tucker and Douglas A. Knight 95-126. California: Scholars Press, 1982.

Fitzmyer, Joseph A. The Letter to Philemon. Doubleday: New York, 2000.

Glancy, Jennifer A. "The Utility of an Apostle: On Philemon 11." Journal of Early Christian History, 5, no.1 (2015): 79.

. "Slavery and the Rise of Christianity." In The Cambridge World History of Slavery, edited by Keith Bradley \& Paul Cartledge, 468-4881. Cambridge, UK: Cambridge University Press, 2011.

Harris, Murray J. Slave of Christ: A New Testament Metaphor for Total Devotion to Christ. Leicester: Apollos, 1999.

Holmes, Michael W. The Apostolic Fathers: Greek Texts and English Translations. Grand Rapids, Mich.: Baker Books, 1999.

Hopkins, Keith. Conquerors and Slaves. Cambridge: Cambridge University Press, 1978. 
Horsely, Richard A. “A Critical Alternative to Recent Readings." Slavery in Text and Interpretation. (1998): 153-200. Jeal, Roy R. Exploring Philemon: Freedom, brotherhood and partnership in the new society. Atlanta: SBL Press, 2015. Kennedy, George A. New Testament interpretation through rhetorical criticism. Chapel Hill, NC: University of North Carolina Press, 1984.

Knox, John. Philemon among the Letters of Paul: A New View of its place and importance. Nashville: Abingdon, 1963.

Koester, Helmut. Introduction to the New Testament: History and Literature of Early Christianity. Philadelphia: Fortress Press, 1982).

Lampe, Peter. "Keine "Sklavenflucht” des Onesimus." Zeitschrift für die neutestamentliche Wissenschaft 76 (1985):13537.

Lohse, Edward. Colossians and Philemon, Philadelphia: Fortress Press, 1971.

Lokkesmoe, Ryan. "Finding Onesimus: Recovering the Story of a First-Century Fugitive Slave." Electronic Theses and Dissertations, 2015.

Longenecker, Richard N. New Wine into Fresh Wineskins: Contextualising the Early Christian Confessions. Peabody, MA: Hendrickson, 1999.

Marchal, Joseph A. "The Usefulness of an Onesimus: The Sexual Use of Slaves and Paul's Letter to Philemon." Journal of Biblical Literature 130, no. 4 (2001): 749-770.

Martin, Clarice J. "The Rhetorical Function of Commercial Language in Paul's Letter to Philemon (Verse 18)." In Persuasive Artistry: Studies in New Testament Rhetoric in Honour of George A. Kennedy, edited by Duane F. Watson, 321 37. London: JSOT Press, 1991.

McKnight, Scot. The letter to Philemon, NICNT. Grand Rapids, Michigan: Eerdmans Press, 2017.

Mitchell, Margaret M. "John Chrysostom on Philemon: A Second Look." Harvard Theological Review 88 (1995): $135-48$.

Moo, Douglas I. The Letters to the Colossians and to Philemon, (Norton Street, Nottingham: Apollos, 2008.

Nordling, John D. "Onesimus fugitivus. A Defense of the Runaway Slave Hypothesis in Philemon." JSNT, 41 (1991): 97-119.

O'Brien, Peter T. Introductory Thanksgivings in the Letters of Paul. Leiden: Brill, 1977.

Olinger, Danny. “A redemptive-historical consideration of Philemon.” NWTS 12, no. 1 (1977): 23-32.

Petersen, Norman R. Rediscovering Paul: Philemon and the Sociology of Paul's Narrative World. Philadelphia: Fortress Press, 1985.

Quintilian. Institutio Oratoria. Translated by H. E. Butler, LCL. Cambridge: Harvard university Press, 1920.

Rapske, Brian M. "The Prisoner Paul in the Eyes of Onesimus." New Testament Studies 37 (1991): 187-203.

Russell, David M. "The Strategy of a First-Century Appeals Letter: A Discourse Reading of Paul's Epistle to Philemon." Journal of Translation and Textlinguistics 11 (1998): 1-25.

Scott, Bartchy S. "Philemon, Epistle to." ABD 5 (1992): 305-310.

Thiselton, C. Anthony. Hermeneutics: An introduction. Grand Rapids, MI: Eerdmans Publishing Company, 2009.

Ukpong, Justin. "Developments in Biblical Interpretation in Africa: Historical and Hermeneutical Directions." In The Bible in Africa: Transactions, Trajectories and Trends, edited by G. O. West and M. Dube, 12-45. Leiden: E. J. Brill, 2000.

Wansink, Craig S. Chained in Christ: The Experience and Rhetoric of Paul's Imprisonment. England: Sheffield Academic Press, 1996.

Winter, Sara B. C. “Methodological Observations on a New Interpretation of Paul's Letter to Philemon." Union Seminary Quarterly Review 39 (1984): 203-212.

"Paul's Letter to Philemon." New Testament Studies, 33, (1987): 5.

Witherington, Ben. The letters to Philemon, the Colossians and the Ephesians: A socio rhetorical commentary on the Captivity Epistles. Grand Rapids: Eerdmans, 2007.

Wright, Nicholas T. The Epistles of Paul to the Colossians and Philemon. Leicester: Intervarsity Press, 1986. 